\title{
Reversed Greenhouse Temperatures Alter Carbohydrate Status in Lilium longiflorum Thunb. 'Nellie White'
}

\author{
William B. Miller ${ }^{1}$ \\ Department of Horticulture, Clemson University, Clemson, SC 29634 \\ P. Allen Hammer and Terri I. Kirk \\ Department of Horticulture, Purdue University, West Lafayette, IN 47907 \\ Additional index words. Easter lily, environmental stress, greenhouse management, Lilium longiflorum, postharvest \\ physiology
}

\begin{abstract}
Commercial greenhouse operators are increasingly using "negative DIF" temperature regimes to control crop height. A negative DIF exists when greenhouse night temperature is greater than the day temperature. Large negative differences in day and night temperatures strongly suppress stem elongation in many crops. We have explored the effects of negative DIF temperature regimes on leaf, flower, and stem carbohydrate levels in Lilium longiflorum Thunb. 'Nellie White'. During two growing seasons, 'Nellie White' plants were grown under positive or negative DIF regimes $( \pm 5$ or $8 \mathrm{C})$ under prevailing daylengths, with temperatures adjusted so that daily temperature averages were equal between regimes. Plants were harvested $\approx 10$ days after visible bud stage and at anthesis. Carbohydrates in stems, leaves, and flowers were analyzed by high-performance liquid chromatography. Compared to plants grown under positive DIF, negative DIF plants showed significantly reduced stem length and leaf and stem dry weights. Negative DIF regimes reduced leaf and stem total soluble carbohydrate (TSC) content by $39 \%$ to $46 \%$ at visible bud and anthesis, while flower TSC content was reduced by $10 \%$ to $13 \%$.
\end{abstract}

Most plants respond to thermoperiodism, or the alteration of day and night temperatures. Went's work in the 1940s indicates that most plants show more vigorous growth when the day temperature is higher then night temperature (Went, 1944, 1957). This work formed the basis for the common practice of maintaining night greenhouse temperatures below day temperatures.

The widespread availability of computerized greenhouse control systems allows creative manipulation of the greenhouse environment and has stimulated research into better ways to use these environmental-control systems. It has been demonstrated that drymatter accumulation in lettuce (Lactuca sativa L.) can be essentially identical using a variety of temperature schemes, as long as 24-hour temperature averages are equal (Miller and Langhans, 1985). Leaf unfolding rates in many plants, including Easter lily, are similar when plants are grown under differing day and night temperature regimes with identical 24-h temperature averages (Karlsson et al., 1988).

More recent research has demonstrated that stem elongation can be controlled substantially by growing plants under higher night than day temperatures. This phenomenon, termed "negative DIF," is effective for Easter lilies (Erwin et al., 1989) and has been adopted in many commercial greenhouses in the United States. Growing plants under warmer nights than days reduces stem elongation and final plant height. Height restriction is greater the greater the difference between day and night temperatures.

Received for publication 11 June 1992. Accepted for publication 19 Mar. 1993 South Carolina Experiment Station paper no. 3405. Journal paper no. 13495 of the Purdue Univ. Agricultural Experiment Station. Support for this research was provided by South Carolina Agricultural Experiment Station Ornamental Horticulture Research Funds; bulb donations from Dahlstrom and Watt Bulb Farms, Smith River, Calif.; and by an equipment grant from the Fred C. Gloeckner Foundation. We gratefully acknowledge the excellent technical assistance of James E. Arnold. The cost of publishing this paper was defrayed in part by the payment of page charges. Under postal regulations, this paper therefore must be hereby marked advertisement solely to indicate this fact.

${ }^{1}$ To whom reprint requests should be addressed.
However, some undesirable effects occur in floriculture crops as a result of negative DIF temperature regimes. Negative DIF increases postharvest cyathia abscission in certain poinsettia $(E u$ phorbia pulcherrima Willd. ex Kl.) cultivars (Moe et al., 1992). With Easter lilies, excessive downward curling of foliage and foliar chlorosis occurred with negative DIF (Erwin et al., 1989). Leaf chlorosis in Lilium 1ongiflorum has been associated with reduced leaf carbohydrate (Jiao et al., 1986).

Although not fully investigated, it may be assumed that, with higher night temperatures, dark respiration will increase and perhaps lead to a decrease in plant carbohydrate pools. Higher night than day temperatures (e.g., 22/14C vs. 14/22C) have been reported to reduce percentage of dry matter in L. longiflorum (Zieslin and Tsujita, 1988). In poinsettia, increasing the night temperature from 9 to $17 \mathrm{C}$ reduced total leaf carbohydrate by $41 \%$ when the day temperature was kept constant at $20 \mathrm{C}$ (Senecal et al., 1989). No information is available concerning effects of negative DIF regimes on levels or partitioning of carbohydrate pools in floricultural crops. Therefore, the objective of this study was to investigate the effects of greenhouse day and night temperatures on starch and soluble carbohydrate pool sizes in Easter lily plants.

\section{Materials and Methods}

General. Two separate experiments were conducted during the 1988-89 and 1990-91 growing seasons. 'Nellie White' $L$. longiflorum bulbs (20 to $23 \mathrm{~cm}$ in circumference) were used in both experiments. In each experiment, bulbs were vernalized for 6 weeks, then planted singly into 1.8 -liter plastic containers using a 1 soil : 2 sphagnum peat : 2 perlite (by volume) mixture amended with $680 \mathrm{~g} \mathrm{0}-44-0,454 \mathrm{~g} \mathrm{KNO}_{3}, 454 \mathrm{~g} \mathrm{MgSO}_{4}, 3.6 \mathrm{~kg}$ ground limestone, and $57 \mathrm{~g}$ trace elements no. 555 (W.R. Grace, Fogelsville, Pa.), all per cubic meter of mix. The plants were fertilized at each watering with $\mathrm{N}$ and $\mathrm{K}$, each at $200 \mathrm{mg} \cdot \mathrm{liter}^{-1}$, supplied from $517 \mathrm{mg}$ $\mathrm{KNO}_{3}$ /liter and $367 \mathrm{mg} \mathrm{NH}_{4} \mathrm{NO}_{3}$ /liter, with $46 \mathrm{mg}$ P/liter supplied via 75\% technical-grade phosphoric acid in the irrigation system. 
About 10 days after visible bud and at anthesis, 10 randomly picked plants from each treatment were harvested. The number of leaves on the main stem (below the inflorescence) was determined at harvest. Tissues were frozen in liquid N, freeze-dried, weighed to determine dry weight, and ground through a 1.25-mm-pore (20mesh) screen before carbohydrate and starch analysis. For leaf analysis, a 25-leaf subsample was randomly collected from each plant. Soluble carbohydrates were extracted and determined using high-performance liquid chromatography, as described previously (Miller and Langhans, 1989). Leaf starch concentration was

Table 1. Plant growth and timing characteristics as affected by a positive $(+)$ or negative $(-)$ DIF regime. The magnitude of DIF was $\pm 5 \mathrm{C}$ in Year 1 and $\pm 8 \mathrm{C}$ in Year 2.

\begin{tabular}{|c|c|c|c|}
\hline Characteristic & + DIF & - DIF & Significance \\
\hline \multicolumn{4}{|c|}{ Year 1} \\
\hline Days to emergence & 28 & 27 & NS \\
\hline Days to visible bud & 75 & 73 & NS \\
\hline Days to anthesis & 112 & 112 & NS \\
\hline Number of leaves & 84.9 & 83.4 & NS \\
\hline Number of buds & 7.5 & 7.8 & NS \\
\hline Stem length $^{\mathrm{z}}$ & 51.4 & 34.1 & $* * *$ \\
\hline Inflorescence length ${ }^{2}$ & 18.8 & 12.6 & $* * *$ \\
\hline Leaf dry weight at visible bud & 3.6 & 3.1 & $*$ \\
\hline Leaf dry weight at anthesis & 8.1 & 6.2 & $*$ \\
\hline Stem dry weight ${ }^{z}$ & 11.8 & 8.9 & $* *$ \\
\hline \multicolumn{4}{|c|}{ Year 2} \\
\hline Days to emergence & 24 & 24 & NS \\
\hline Days to visible bud & 87 & 88 & NS \\
\hline Days to anthesis & 122 & 120 & NS \\
\hline Number of leaves & 76.4 & 82.2 & NS \\
\hline Number of buds & 5.5 & 5.4 & NS \\
\hline Stem length ${ }^{2}$ & 33.8 & 18.9 & $* * *$ \\
\hline Leaf dry weight at visible bud & 6.4 & 4.8 & $* * *$ \\
\hline Leaf dry weight at anthesis & 9.1 & 6.6 & $* * *$ \\
\hline Flower dry weight at visible bud & 0.5 & 0.6 & NS \\
\hline Flower dry weight at anthesis & 7.3 & 6.3 & NS \\
\hline Stem dry weight at visible bud & 3.4 & 2.0 & $* * *$ \\
\hline Stem dry weight at anthesis & 8.8 & 4.9 & $* * *$ \\
\hline
\end{tabular}

${ }^{\mathrm{z}}$ Data collected at anthesis.

Ns, ${ }^{* * *},{ }^{* * *}$ Nonsignificant or significant at $0.01 \geq P>0.001$, or $P \leq 0.001$, respectively. determined via a glucose oxidase method following amyloglucosidase hydrolysis of the insoluble residue (Miller and Langhans, 1989).

Days to visible bud and anthesis were calculated from the date the bulbs were planted and placed in the greenhouse. Anthesis was recorded when the first flower opened. The number of flower buds, stem length (from the soil surface to the base of the inflorescence), and inflorescence length (from the top stem leaf to the highest flower bud, Expt. 1 only) were also recorded. Mother and daughter scale dry weight was determined after tissues were held for 3 days at $70 \mathrm{C}$.

Expt. 1. On 29 Nov. 1988, bulbs were planted and placed into a 21/16C (day/night) greenhouse, with the prevailing photoperiod ( $\approx$ 9-h day and 15-h night). After plant emergence on 19 Jan. 1989, temperature cycles $( \pm 0.5 \mathrm{C})$ of $21 / 16 \mathrm{C}(+\mathrm{DIF})$ or $16 / 21 \mathrm{C}(-\mathrm{DIF})$ were imposed for 11 days. Then, to equalize average daily temperatures, on $30 \mathrm{Jan}$., final temperature cycles $( \pm 0.5 \mathrm{C})$ of $21 / 15.5 \mathrm{C}$ (+DIF) and 14.5/19.5C (-DIF) were imposed using the same time periods as above. Plants were harvested on $20 \mathrm{Feb}$. (average date of visible bud: $10 \mathrm{Feb}$.) and 21 Mar. (average date of anthesis: 21 Mar.).

Expt. 2. On 28 Nov. 1990, bulbs were planted and placed into either a $24 / 15.5 \mathrm{C}(+\mathrm{DIF})$ or 13.5/21.5C (-DIF) greenhouse with the prevailing 9-h photoperiod. These temperatures gave equal average daily temperatures and were maintained until anthesis. Plants were harvested 5 Mar. 1991 (average date of visible bud: Feb. 22) and 2 Apr. (average date of anthesis: 28 Mar.).

Ten plants randomly selected at each harvest from each temperature treatment were considered as individual replicates and subjected to standard analysis of variance. Since the results for the years' varied slightly, they were analyzed separately but could be considered replications of the temperature treatments when viewing the overall results.

\section{Results}

In both years, there were no differences between the treatments in days to emergence, visible bud, or anthesis or in the number of leaves or buds per plant (Table 1). These responses were expected because Easter lily development is highly dependent on average daily temperature; these data indicate that equal 24-h average temperatures were maintained between the treatments.

In Year 1, temperature regime caused no significant differences in mother or daughter bulb dry weight at either growth stage (data not presented). These data were not collected in Year 2.

In Year 1, the negative DIF temperature regime significantly reduced stem elongation and stem dry weight, relative to the

Table 2. Effect of positive ( $+5 \mathrm{C}$ ) or negative (-5C) DIF greenhouse temperature regimes on the carbohydrate concentration of Easter lily leaves. 'Nellie White' plants were grown under the indicated regime, then harvested at visible bud plus 10 days or at anthesis. Values are the means of 10 replications per treatment (Expt. 1).

\begin{tabular}{|c|c|c|c|c|c|}
\hline \multirow[b]{2}{*}{ DIF } & \multicolumn{5}{|c|}{ Carbohydrate concn $\left(\mathrm{mg} \cdot \mathrm{g}^{-1} \mathrm{dry} \mathrm{wt}\right)$} \\
\hline & Sucrose & Unknown $^{z}$ & Glucose & Fructose & $\mathrm{TSC}^{\mathrm{y}}$ \\
\hline \multicolumn{6}{|c|}{ Visible bud +10 days } \\
\hline+ & 96.1 & 34.3 & 26.5 & 35.6 & 192.4 \\
\hline- & 84.8 & 33.3 & 10.9 & 17.8 & 146.8 \\
\hline Significance & NS & NS & $* * *$ & $* * *$ & $* *$ \\
\hline \multicolumn{6}{|c|}{ Anthesis } \\
\hline+ & 47.9 & 12.7 & 14.8 & 25.9 & 101.3 \\
\hline- & 33.2 & 15.8 & 14.1 & 23.8 & 86.9 \\
\hline Significance & $*$ & NS & NS & NS & $*$ \\
\hline
\end{tabular}

${ }^{\mathrm{z}}$ Unknown is a currently unidentified carbohydrate eluting between sucrose and glucose. yTSC = total soluble carbohydrate; the sum of sucrose, unknown, glucose, and fructose. Ns, ${ }^{* * * *, * * *}$ Nonsignificant or significant at $0.05 \geq P>0.01,0.01 \geq P>0.001$, or $P \leq 0.001$, respectively. 
positive DIF regime (Table 1). Reduced main stem (soil level to base of inflorescence) and inflorescence length contributed to overall reduced plant height. The negative DIF temperature regime reduced leaf dry weight, reducing sugars, and total leaf soluble carbohydrate (TSC) concentration (mg carbohydrate/g dry weight) at visible bud (Tables 1 and 2). At anthesis, leaf dry weight, sucrose, and TSC were reduced by the negative DIF regime, but reducing sugars were not affected. An unknown soluble carbohydrate was not affected by temperature regime at either stage (Table $2)$. While the identity of this compound is currently unknown, some of its characteristics have been described (Miller and Langhans, 1989).

In the second year, the overall trend of negative DIF's reducing carbohydrate level was repeated. At both growth stages, the negative DIF regime significantly reduced dry weight of leaves and stems, but flower dry weight was not affected (Table 1). In leaves, the negative DIF regime reduced sucrose, glucose, fructose, TSC, and total carbohydrate (TC) concentrations at visible bud and anthesis (Table 3). Leaf starch concentration was at least lo-fold lower than TSC and was not affected by temperature regime. The unknown was increased in leaves by the negative DIF regime at anthesis. In flower buds at visible bud, all individual carbohydrate pools, except the unknown, were reduced in plants grown under the negative DIF regime. At anthesis, however, most pools were similar for the temperature treatments. In stems, reducing-sugar concentrations were consistently lower in plants grown under the negative DIF regime at both growth stages. TSC and TC were not affected by temperature regime, however, due to the somewhat higher concentration of the unknown in the plants grown under the negative DIF regime (Table 3).

When expressed per organ, leaf and stem carbohydrate content were greatly reduced by the negative DIF regime at visible bud and anthesis (Table 4). In leaves, the content of all soluble carbohydrates (except the unknown) were reduced by the negative DIF regime, with $\mathrm{a} \approx 40 \%$ reduction overall. Starch content was reduced in leaves by the negative DIF regime at visible bud but not at anthesis. In flowers, temperature regime did not alter the content of most individual carbohydrates or TSC and TC, although negative DIF reduced sucrose content and increased that of the unknown at anthesis. In stems, the content of all soluble sugars were reduced by the negative DIF treatment, with an overall TSC reduction averaging $44 \%$. Stem starch pools were low and were not affected by the temperature treatments.

\section{Discussion}

In this report, we document substantial reductions in carbohydrate pools in Easter lily plants grown under cool day and warm night (negative DIF) temperature regimes, relative to plants grown under warm day and cool night (positive DIF) regimes. These reductions occurred in two experiments conducted during 2 years. Leaves showed the most consistent decrease in carbohydrate as a result of the negative DIF regime; total canopy carbohydrate content was reduced $40 \%$ at both growth stages examined. Leaf

Table 3. Effect of positive $(+8 \mathrm{C})$ or negative $(-8 \mathrm{C})$ DIF greenhouse temperature regimes on the carbohydrate concentration of Easter lily leaves, flowers, or stems. 'Nellie White' plants were grown under the indicated regime, then harvested at visible bud plus 10 days or at anthesis. Values are the means of 10 replications per treatment (Expt. 2).

\begin{tabular}{|c|c|c|c|c|c|c|c|}
\hline \multirow[b]{2}{*}{ DIF } & \multicolumn{7}{|c|}{ Carbohydrate concn (mg. $\mathrm{g}^{-1}$ dry wt) } \\
\hline & Sucrose & Unknown $^{2}$ & Glucose & Fructose & $\mathrm{TSC}^{\mathrm{y}}$ & Starch & $\mathrm{TC}^{\mathrm{x}}$ \\
\hline \multicolumn{8}{|c|}{ Leaves-visible bud +10 days } \\
\hline+ & 55.5 & 27.9 & 37.4 & 48.4 & 169.2 & 14.4 & 183.6 \\
\hline- & 41.0 & 28.9 & 26.1 & 40.2 & 136.2 & 12.7 & 148.9 \\
\hline Significance & $* * *$ & NS & $* * *$ & $*$ & $* *$ & NS & $* * *$ \\
\hline \multicolumn{8}{|c|}{ Leaves-anthesis } \\
\hline+ & 81.9 & 24.8 & 21.3 & 36.3 & 164.3 & 7.4 & 171.7 \\
\hline- & 65.4 & 32.1 & 14.2 & 25.7 & 137.4 & 6.4 & 143.8 \\
\hline Significance & $* * *$ & $* * *$ & $*$ & $* *$ & $* *$ & NS & $* *$ \\
\hline \multicolumn{8}{|c|}{ Flowers-visible bud +10 days } \\
\hline+ & 49.0 & 10.2 & 12.5 & 15.6 & 87.4 & 75.8 & 163.1 \\
\hline- & 42.2 & 11.0 & 9.8 & 13.2 & 76.2 & 64.9 & 141.1 \\
\hline Significance & $* * *$ & NS & $*$ & $* *$ & $* * *$ & $*$ & $* * *$ \\
\hline \multicolumn{8}{|c|}{ Flowers-anthesis } \\
\hline+ & 72.1 & 4.3 & 63.8 & 72.2 & 212.4 & 36.9 & 249.3 \\
\hline- & 61.4 & 8.7 & 56.4 & 65.3 & 191.8 & 45.3 & 237.1 \\
\hline Significance & $* *$ & $* * *$ & NS & NS & NS & NS & NS \\
\hline \multicolumn{8}{|c|}{ Stems-visible bud +10 days } \\
\hline+ & 24.9 & 155.4 & 27.9 & 22.6 & 230.8 & 1.1 & 231.9 \\
\hline- & 23.2 & 163.7 & 14.4 & 12.5 & 213.8 & 2.0 & 215.8 \\
\hline Significance & NS & NS & $* * *$ & $* * *$ & NS & NS & NS \\
\hline \multicolumn{8}{|c|}{ Stems-anthesis } \\
\hline+ & 49.7 & 100.8 & 16.8 & 21.3 & 188.6 & 2.4 & 191.0 \\
\hline- & 44.6 & 126.2 & 10.6 & 14.8 & 196.1 & 3.1 & 199.3 \\
\hline Significance & NS & $* *$ & $* *$ & $* * *$ & NS & NS & NS \\
\hline
\end{tabular}

$\bar{z}$ Unknown is a currently unidentified carbohydrate eluting between sucrose and glucose. ${ }^{\mathrm{y} T S C}=$ total soluble carbohydrate, the sum of sucrose, unknown, glucose, and fructose. ${ }^{\mathrm{x}} \mathrm{TC}=$ total carbohydrate; the sum of TSC plus starch.

Ns, ${ }^{*}, * *, * * *$ Nonsignificant or significant at $0.05 \geq P>0.01,0.01 \geq P>0.001$, or $P \leq 0.001$, respectively. 
dry weight was also substantially reduced by negative DIF. In flowers and stems, the main plant sinks during greenhouse forcing, negative DIF either had no or only transient effects. In flowers, negative DIF reduced TSC and starch concentrations, but these differences disappeared by anthesis, and at no time was the inflorescence total carbohydrate content or dry weight reduced. Stem carbohydrate concentrations were similarly unaffected by the negative DIF regime; but, due to restricted elongation and dry weight gain, stem carbohydrate content was reduced by $44 \%$. Our work demonstrates that the relationship between day and night temperatures (DIF) influences plant height (Erwin et al., 1989) and dry weight and affects carbohydrate partitioning and pool sizes. Our results support those of Zieslin and Tsujita (1988), who found that negative DIF regimes reduce dry-matter percentage in $L$. longiflorum.

To explain these adverse effects of negative DIF on plant dry weight, photosynthesis and respiration must be considered. Reduced carbohydrate pool sizes may result from reduced input (reduced photosynthetic rates or import from other organs) or from increased use (higher respiration rates, export to other organs, or incorporation into other compounds). Although the light reactions of photosynthesis are essentially unaffected by temperature within normal physiological or commercial cultural limits, the enzymatically driven dark reactions have a strong temperature response, with a $Q_{10}$ typically near 2 (Bidwell, 1979). Because of this, total $\mathrm{C}$ fixation of plants grown under a day temperature 5 to $8 \mathrm{C}$ lower (as in our experiments) would be expected to be somewhat less than that obtained with warmer day temperatures.

This effect may be offset, particularly under the low light conditions prevailing at the beginning and end of the day, by a reduced rate of dark respiration at the lower day temperature. In this case, plant carbohydrate concentrations at the start of the dark period in plants grown under the negative DIF regime may be higher than those in plants grown under zero or positive DIF regimes. In many plant tissues, dark respiration is closely and positively correlated with respirable sugar concentration (AzconBieto and Osmond, 1983; Challa, 1976) and may proceed at a higher rate immediately following the end of the light period (e.g., in maize; Heichel, 1970). In L. longiforum grown under a negative DIF regime, this could lead to rapid respiration of accumulated leaf sugar in the early hours of the warm night and a concomitant reduction in carbohydrate concentration, relative to plants grown under a positive DIF regime. Further work is required to test this hypothesis.

In general, the reductions in plant carbohydrate caused by negative DIF may be undesirable from a postproduction viewpoint, since, in many species, postharvest performance is improved by cultural practices expected to increase plant carbohydrates. Begonia $\times$ cheimantha (Everett) plants produced at low light levels show decreased postharvest performance, with flower abscission negatively correlated to plant sucrose and starch concentrations (Fjeld, 1986, 1992). The postharvest life of carnation (Dianthus caryophyllus L.) and 'Enchantment' lily is greatest when plants are grown during the high-light periods of the year

Table 4. Effect of positive $(+8 \mathrm{C})$ or negative $(-8 \mathrm{C})$ DIF greenhouse temperature regimes on the carbohydrate content (per organ) of Easter lily leaves, flowers, or stems. 'Nellie White' plants were grown under the indicated temperature regimes, then harvested at visible bud plus 10 days or at anthesis. Values are the means of 10 replications per treatment (Expt. 2).

\begin{tabular}{|c|c|c|c|c|c|c|c|}
\hline \multirow[b]{2}{*}{ DIF } & \multirow[b]{2}{*}{ Sucrose } & \multicolumn{4}{|c|}{ Carbohydrate content (mg/organ) } & \multirow[b]{2}{*}{ Starch } & \multirow[b]{2}{*}{$\mathbf{T C}^{\mathbf{x}}$} \\
\hline & & Unknown ${ }^{\mathrm{z}}$ & Glucose & Fructose & $\mathrm{TSC}^{\mathrm{y}}$ & & \\
\hline \multicolumn{8}{|c|}{ Leaves-visible bud +10 days } \\
\hline+ & 358 & 184 & 242 & 314 & 1097 & 93 & 1190 \\
\hline- & 199 & 144 & 128 & 198 & 669 & 62 & 731 \\
\hline Significance & $* * *$ & NS & $* * *$ & $* *$ & $* * *$ & $* *$ & $* * *$ \\
\hline \multicolumn{8}{|c|}{ Leaves-anthesis } \\
\hline+ & 743 & 225 & 197 & 333 & 1498 & 65 & 1563 \\
\hline- & 430 & 214 & 90 & 166 & 899 & 43 & 942 \\
\hline Significance & $* * *$ & NS & $* * *$ & $* * *$ & $* * *$ & NS & $* * *$ \\
\hline \multicolumn{8}{|c|}{ Flowers-visible bud +10 days } \\
\hline+ & 23.8 & 5.4 & 6.4 & 7.6 & 43 & 37 & 80 \\
\hline- & 22.8 & 7.3 & 5.6 & 7.2 & 42 & 36 & 79 \\
\hline Significance & NS & NS & NS & NS & NS & NS & NS \\
\hline \multicolumn{8}{|c|}{ Flowers-anthesis } \\
\hline+ & 525 & 30.9 & 468 & 529 & 1553 & 269 & 1822 \\
\hline- & 384 & 56.4 & 379 & 440 & 1258 & 279 & 1537 \\
\hline Significance & $* *$ & $* *$ & NS & NS & NS & NS & NS \\
\hline \multicolumn{8}{|c|}{ Stems-visible bud + 10 days } \\
\hline+ & 82 & 527 & 97 & 80 & 786 & 4 & 790 \\
\hline- & 45 & 328 & 29 & 25 & 427 & 4 & 431 \\
\hline Significance & $* * *$ & $* *$ & $* * *$ & $* * *$ & $* * *$ & NS & $* * *$ \\
\hline \multicolumn{8}{|c|}{ Stems-anthesis } \\
\hline+ & 443 & 897 & 152 & 192 & 1684 & 21 & 1705 \\
\hline- & 219 & 622 & 51 & 72 & 964 & 15 & 979 \\
\hline Significance & $* * *$ & $* *$ & $* * *$ & $* * *$ & $* * *$ & NS & $* * *$ \\
\hline
\end{tabular}

${ }^{2}$ Unknown is a currently unidentified carbohydrate eluting between sucrose and glucose.

${ }^{\mathrm{y}} \mathrm{TSC}=$ total soluble carbohydrate; the sum of sucrose, unknown, glucose, and fructose.

${ }^{\mathrm{x}} \mathrm{TC}=$ the sum of TSC and starch.

${ }_{\text {Ns, }, * * *, * * *}$ Nonsignificant or significant at $0.05 \geq P>0.01,0.01 \geq P>0.001$, or $P \leq 0.001$, respectively. 
(Heide and Oydvin, 1969; Swart, 1980). In poinsettia, carbohydrate-depleting treatments (low irradiance, leaf shading, leaf removal, dense plant spacing, negative DIF) increase cyathia abscission (Miller and Heins, 1986; Moe et al., 1992), but plants conditioned by 1 to 3 weeks of low light before harvest exhibit less leaf abscission 30 days postanthesis (Nell and Barrett, 1986). Poinsettias grown under reduced irradiance abscise more cyathia but fewer leaves 30 days postanthesis (Bailey and Miller, 1991). We were unable to assess plant postharvest longevity within the current experiments. In view of the apparent relationship of high carbohydrates to optimum postproduction performance, and specifically with implications to lily leaf chlorosis (Jiao, et al. 1986; Tsujita et al., 1978), investigations into interactions of temperature management practices and Easter lily postharvest longevity are warranted.

\section{Literature Cited}

Azcon-Bieto, J. and C.B. Osmond. 1983. Relationship between photosynthesis and respiration. The effect of carbohydrate status on the rate of $\mathrm{CO}_{2}$ production by respiration in darkened and illuminated wheat leaves. Plant Physiol. 71:574-581.

Bailey, D.A. and W.B. Miller. 1991. Poinsettia developmental and postproduction responses to growth retardants and irradiance. HortScience 26:1501-1503.

Bidwell, R.G.S. 1979. Plant physiology. 2nd ed. MacMillan, New York. Challa, H. 1976. An analysis of the diurnal course of growth, carbon dioxide exchange and carbohydrate reserve content of cucumber. Agr. Res. Rpt. 861. Wageningen, The Netherlands.

Erwin, J.E., R.D. Heins, and M. Karlsson. 1989. Thermomorphogenesis in Lilium longiflorum. Amer. J. Bot. 76:47-52.

Fjeld, T. 1986. The effect of relative humidity, light intensity, and temperature on the keeping quality of Begonia $\times$ cheimantha Everett. Acta Hort. 181:251-255.

Fjeld, T. 1992. Effects of temperature and it-radiance level on carbohydrate content and keeping quality of Christmas begonia (Begonia $\times$ cheimantha Everett). Scientia Hort. 50:219-228.

Heichel, G.H. 1970. Prior illumination and the respiration rate of maize leaves in the dark. Plant Physiol. 46:359-362.

Heide, O.M. and J. Oydvin. 1969. Effects of 6-benzylaminopurine on the keeping quality and respiration of glass house carnation. Hort. Res. 9:26-36.

Jiao, J., M.J. Tsujita, and D.P. Murr. 1986. Effects of paclobutrazol and Arest on growth, flowering, leaf carbohydrate, and leaf senescence in 'Nellie White' Easter lily (Lilium longiflorum Thunb). Scientia Hort. 30:135-141.

Karlsson, M.G., R.D. Heins, and J.E. Erwin. 1988. Quantifying temperature-controlled leaf unfolding rates in 'Nellie White' Easter lily. J. Amer. Soc. Hort. Sci. 113:70-74.

Miller, S.H. and R.D. Heins. 1986. Factors influencing premature cyathia abscission in poinsettia 'Annette Hegg Dark Red.' J. Amer. Soc. Hort. Sci. 111:114-121.

Miller, W.B. and R.W. Langhans. 1985. Growth and productivity of 'Grand Rapids' lettuce in diurnally fluctuating temperatures and day/ night average temperatures. J. Amer. Soc. Hort. Sci. 110:560-566.

Miller, W.B. and R.W. Langhans. 1989. Carbohydrate changes of Easter lilies during growth in normal and reduced irradiance environments. J. Amer. Soc. Hort. Sci. 114:310-315.

Moe, R., T. Fjeld, and L.M. Mortensen. 1992. Stem elongation and keeping quality in poinsettia (Euphorbia pulcherrima Willd.) as affected by temperature and supplementary lighting. Scientia Hort. 50:127-136.

Nell, T.A. and J.E. Barrett. 1986. Production light level effects on light compensation point, carbon exchange rate, and post-production longevity of poinsettias. Acta Hort. 181:257-262.

Senecal, M.B. Dansereau, and R. Paquin. 1989. Fertilization and night temperature effects on growth and carbohydrate status of poinsettia. Can. J. Plant Sci. 69:347-349.

Swart, A. 1980. Quality of Lilium 'Enchantment' flowers as influenced by season and silver thiosulphate. Acta Hort. 113:45-49.

Tsujita, M.J., D.P. Murr, and A.G. Johnson. 1978. Influence of phosphorus nutrition and ancymidol on leaf senescence and growth of Easter lily. Can. J. Plant Sci. 58:287-290.

Went, F.W. 1944. Plant growth under controlled conditions. I. Thermoperiodicity in growth and fruiting of the tomato. Amer. J. Bot. 31: 135-150.

Went, F.W. 1957. The experimental control of plant growth. Chronica Botanica Co., Waltham, Mass.

Zieslin, N. and M.J. Tsujita. 1988. Regulation of stem elongation of lilies by temperature and the effect of gibberellin. Scientia Hort. 37:165-169. 